EXPERIMENTAL STUDY

\title{
Functional in vitro studies on the role and regulation of interleukin-6 in human somatotroph pituitary adenomas
}

Jan-Oliver Thiele, Penny Lohrer, Ludwig Schaaf, Manuela Feirer, Walter Stummer ${ }^{1}$, Marco Losa ${ }^{2}$, Manfred Lange ${ }^{3}$, Maria Tichomirowa, Eduardo Arzt ${ }^{4}$, Günter K Stalla and Ulrich Renner

Max-Planck-Institute of Psychiatry, Department of Endocrinology, Kraepelinstr. 10, D-80804 Munich, Germany, ${ }^{1}$ Department of Neurosurgery,

University of Munich, Germany, ${ }^{2}$ Hospital San Raffaele, Milan, Italy, ${ }^{3}$ Klinikum of Villingen-Schwenningen, Germany and ${ }^{4}$ Laboratorio de Fisiologia $y$ Biologia Molecular, Department Fisiologia y Biologia Molecular, FCEN-Universidad de Buenos Aires and IFIBYNE-CONICET, Buenos Aires, Argentina

(Correspondence should be addressed to U Renner; Email: renner@mpipsykl.mpg.de)

\begin{abstract}
Objective: Interleukin-6 (IL-6), a member of the gp130 cytokine family, is considered to be an important modulator of function and growth in endocrine anterior pituitary cells. In pituitary adenomas, where IL-6 is often produced by the tumour cells, it is thought to be involved in pituitary adenoma pathophysiology via autocrine/paracrine mechanisms.

Methods: We have studied in primary cell cultures of human somatotroph adenomas whether IL-6 stimulates growth hormone secretion and whether intratumoral IL-6 is affected by various IL-6-regulating factors.

Results: Interleukin-6 stimulated GH secretion in 10 out of 11 somatotroph adenoma cultures (1.4- to 6.5-fold above basal levels). In comparative studies the GH-stimulatory potency of IL-6 was identical, or even stronger, than that of GHRH. In eight out of 11 adenoma cell cultures, IL- 6 production was observed. This suggests that GH production might be stimulated by IL- 6 in an autocrine/paracrine manner in these tumours. Dexamethasone strongly inhibited basal IL-6 secretion in all IL-6-producing adenoma cell cultures, whereas the IL-6 inhibitory or stimulatory action of other factors (octreotide, transforming growth factor- $\beta 1$, insulin-like growth factor-I, pituitary adenylate cyclase-activating peptide and oestradiol) were heterogeneous in the different adenomas. Only transforming growth factor- $\alpha$ consistently stimulated IL- 6 secretion in all of the adenomas studied.

Conclusions: Intratumoral IL-6, which is differently regulated by various factors, might contribute to excessive GH production in the majority of somatotroph adenomas.
\end{abstract}

European Journal of Endocrinology 149 455-461

\section{Introduction}

Interleukin-6 (IL-6), IL-11, leukemia inhibitory factor (LIF), ciliary neurotrophic factor (CNTF), oncostatin $\mathrm{M}$, and cardiotrophin-1 are all members of the gp130 cytokine family, which act through receptors coupled to the gp130 signal transducer. Most of these cytokines are known to affect anterior pituitary development, function and growth (1). Among them, IL-6 has been shown to inhibit the growth of normal endocrine pituitary cells and to stimulate the proliferation of pituitary tumour cells (2-4). IL-6 stimulates adrenocorticotrophin (ACTH), growth hormone $(\mathrm{GH})$, prolactin (PRL), luteinising hormone and follicle-stimulating hormone secretion in normal anterior pituitary $(5,6)$ and $\mathrm{GH}$ and PRL in lactosomatotroph GH3 rat pituitary tumour cells (2). In corticotroph adenomas, the stimulation of pro-opiomelanocortin mRNA expression and ACTH secretion by IL- 6 has also been demonstrated (7).

In the normal pituitary, IL- 6 is produced by folliculostellate (FS) cells $(8,9)$, a star-shaped cell type which is immunopositive for $\mathrm{S} 100$ protein and glial fibrillary acidic protein (10). Different functions have been attributed to this cell type (10); it does not produce hormones but produces a number of growth factors and cytokines, among them IL-6 and other gp130 cytokines such as LIF and CNTF $(11,12)$. The production of IL- 6 by FS cells is regulated by factors related to the immune system or the neuroendocrine system. Bacterial endotoxin (LPS), IL-1, tumor necrosis factor$\alpha$, pituitary adenylate cyclase-activating peptide (PACAP), vasoactive intestinal peptide and calcitonin all stimulate IL-6 production via specific receptors and different signalling pathways $(5,13,14)$. Glucocorticoid receptors expressed in FS cells (15) mediate the potent inhibitory effects of glucocorticoids on IL-6 production $(8,13)$.

In the majority of pituitary adenomas, where FS cells are absent or rare, the tumour cells themselves produce IL-6 (16-20). Therefore, IL-6 is thought to affect pituitary adenoma pathophysiology and development by autocrine/paracrine mechanisms $(5,6)$ through intratumoral IL- 6 receptors $(20,21)$. To date, the intratumoral regulation of IL- 6 production has not been 
completely elucidated; so far it has only been shown that glucocorticoids suppress IL-6 in corticotroph adenomas (7) and that IL-1 is able to stimulate IL-6 in various types of pituitary tumours (22). In the present paper, we are the first to demonstrate the regulation of IL-6 production in somatotroph pituitary tumours as well as the effect of IL-6 on tumoral GH secretion.

\section{Materials and methods}

\section{Patients}

The present study was approved by the ethics committee of the Max-Planck-Institute of Psychiatry (Munich, Germany) and was undertaken after informed consent was received from each patient. Tumour specimens (numbered ST1-ST11) were obtained from 11 patients (five females, six males; age range: 23 to 64 years; mean age: $44 \pm 15$ years) after transsphenoidal surgery. Nuclear magnetic resonance imaging showed that all patients had macroadenomas with para- and/or suprasellar extension. At diagnosis, GH (range: $18-83 \mu \mathrm{g} / \mathrm{l}$ ) and insulin-like growth factor-I (IGF-I; range: $862-$ $2512 \mu \mathrm{g} / \mathrm{l})$ serum levels were elevated in all patients and endocrine testing showed inappropriate responses to the oral glucose tolerance test in all cases. Routine immunohistological characterisation of the tumours showed that nine adenomas were immunopositive for GH only, whereas scattered PRL-immunopositive cells were also detected in two tumours. However, in none of the patients were serum PRL levels elevated. Before transsphenoidal surgery, all but one of the patients (ST10) had been pretreated with octreotide.

\section{Materials}

Cell culture reagents and materials were purchased from Flow Laboratories (Meckenheim, Germany), Gibco BRL Life Technologies (Eggenstein, Germany), Seromed (Berlin, Germany), Sigma Chemical Co. (St Louis, MO, USA), Falcon (Heidelberg, Germany) or Nunc (Wiesbaden, Germany). Dexamethasone and oestradiol (E2) were obtained from Sigma Chemical Co., PACAP-38 and GH-releasing hormone (GHRH) were from Bachem (Bubendorf, Switzerland), transforming growth factor (TGF)- $\alpha$, TGF- $\beta 1$ and IGF-I were from R\&D Systems (Wiesbaden, Germany), and octreotide was from Novartis (Nuremburg, Germany).

\section{Cell culture}

Human pituitary adenoma tissue was dispersed as previously described (23). The cells were washed by repetitive centrifugation and resuspension, and were finally resuspended in DMEM culture medium ( $\mathrm{pH} 7.3$ ) which was supplemented with $10 \%$ fetal calf serum (FCS), $2.2 \mathrm{~g} / \mathrm{l} \mathrm{NaHCO}_{3}, 10 \mathrm{mmol} / \mathrm{l}$ HEPES, $2 \mathrm{mmol} / \mathrm{l}$ glutamine, $10 \mathrm{ml} / \mathrm{l}$ non-essential amino acids, $10 \mathrm{ml} / \mathrm{l}$ MEM vitamins, $5 \mathrm{mg} / \mathrm{l}$ insulin, $5 \mathrm{mg} / \mathrm{l}$ transferrin, $2.5 \mathrm{mg} / \mathrm{l}$ amphotericin-B, $10^{5} \mathrm{U} / \mathrm{l}$ penicillin/streptomycin, $20 \mu \mathrm{g} / \mathrm{l}$ sodium selenite, and $30 \mathrm{pmol} / \mathrm{l}$ triiodothyronine ( $\mathrm{T}_{3}$; Henning, Berlin, Germany). Cell viability was consistently over $90 \%$ as assessed by acridine orange/ethidium bromide staining. The cells were plated in 48 -well plates $(100000$ cells/well in $0.5 \mathrm{ml}$ culture medium) and incubated for 2 to 3 days in a $5 \% \mathrm{CO}_{2}$ atmosphere at $37^{\circ} \mathrm{C}$. After the cells had attached to the plates, they were stimulated as described below. The small amount of tissue available limited the number of parallel experiments that could be carried out with each tumour.

\section{Determination of basal and stimulated IL-6 production by adenoma cells}

Before measuring the basal or stimulated IL-6 production, the initial culture medium was removed, and the cells were washed with phosphate-buffered saline (PBS) and then cultivated in serum-free medium for $24 \mathrm{~h}$ to remove any residual FCS. After the serum washout period, the adenoma cell cultures were cultivated for an additional $24 \mathrm{~h}$ in fresh serum-free medium without (basal IL-6 production) and with different stimuli as indicated. At the end of the incubation time, the cell culture supernatants were harvested and centrifuged. Human IL-6 was measured in the supernatants by ELISA (R\&D Systems) according to the manufacturer's instructions and as previously described (7). To calculate basal IL-6 production with respect to cell numbers, unstimulated cells were removed from their plastic substrate with a short treatment of trypsin and then counted with an adapted Coulter counter, as previously described (24). In all stimulation experiments, the amount of $0.5 \mathrm{ml}$ cell culture supernatant was sufficient only for IL- 6 determination and therefore it was not possible to measure $\mathrm{GH}$ in parallel.

\section{Stimulation and measurement of GH}

Cell cultures were stimulated with recombinant human IL-6 (Roche, Mannheim, Germany) according to our previous experience with interleukins $(2,4)$. IL-6 was dissolved in $0.05 \%$ BSA (crystallised and lyophilised, $99 \%$ purity). The same volume of diluent was added to the unstimulated (basal) wells. Each somatotroph cell culture was stimulated with $50 \mathrm{nmol} / \mathrm{l}$ IL-6. If enough cells were available, dose-response studies $(0.5-50 \mathrm{nmol} / \mathrm{l} \mathrm{IL}-6$ corresponding to $0.1-10 \mathrm{ng} / \mathrm{ml}$ IL-6) were also performed. In some cases, the cells were also stimulated with $10 \mathrm{nmol} / \mathrm{l}$ GHRH. After a stimulation period of $24 \mathrm{~h}, \mathrm{GH}$ was determined in the cell culture supernatants using a fluorescence immunoassay (FIA) as previously described (23). 


\section{Statistics}

Experiments were performed either in triplicate wells (GH production) or in quadruplicate wells (IL-6 production). Results are expressed as means \pm S.E. Statistics were performed by ANOVA in combination with Scheffe's test.

\section{Results}

\section{Influence of IL-6 on basal GH production}

Due to the limited amount of tissue, only the effect of $50 \mathrm{nmol} / \mathrm{l} \mathrm{IL-6}$ on GH secretion could be studied in each of the adenoma cell cultures. We found that the heterogeneous basal GH secretion in the different adenoma cell cultures was stimulated by $50 \mathrm{nmol} / \mathrm{l} \mathrm{IL-6}$ in 10 out of 11 cases (Fig. 1). In one adenoma cell culture (ST11) which had high basal GH levels, IL-6 did not stimulate GH secretion further. In 5 out of 11 adenoma cell cultures, the effect of $10 \mathrm{nmol} / \mathrm{l} \mathrm{GHRH}$ on GH secretion was studied in parallel to IL-6 (2 examples are shown in Fig. 2). In two adenoma cell cultures (ST8, ST9), GHRH significantly stimulated GH production, whereas three adenomas (ST7, ST10, ST11) did not respond to GHRH; among these were the two adenomas (ST10, ST11) which had the highest basal IL-6 levels and the one (ST11) in which IL-6 was also not effective. Dose-response studies with IL-6 $(0.5,5$ and $50 \mathrm{nmol} / \mathrm{l})$ were performed in four adenoma cell cultures (ST7, ST8, ST9, ST10; two examples are shown in Fig. 2). In two out of four adenoma cultures, $0.5 \mathrm{nmol} / \mathrm{l} \mathrm{IL-} 6$ significantly stimulated GH secretion (Fig. 2). Maximum stimulation was achieved at $5 \mathrm{nmol} / \mathrm{l} \mathrm{IL-} 6$ and no further significant increase in $\mathrm{GH}$ secretion was obtained after application of $50 \mathrm{nmol} / \mathrm{l}$ IL- 6 in all four adenoma cultures.

\section{Regulation of IL-6 secretion in somatotroph adenoma cell cultures}

Eight out of 11 adenomas (73\%) basally produced heterogeneous amounts of IL-6 (indicated for each tumour on top of the bars in Fig. 3), ranging from 10.2 \pm 0.9 to $189.7 \pm 16.3$ pg IL- 6 per 100000 cells per $24 \mathrm{~h}$. In the monolayer cell cultures, a tendency (the number of tumours was too small for exact statistical analysis) for no relationship between GH and IL- 6 secretion was observed, since tumours which released low amounts of GH secreted high quantities of IL-6 (e.g. ST4) and vice versa (e.g. ST1). This suggests that IL-6 and $\mathrm{GH}$ are independently produced by the adenoma cells. To study the regulation of adenomatous IL- 6 secretion, adenoma cell cultures were treated with regulators of IL-6 production (dexamethasone, PACAP), effectors of somatotroph cells (GHRH, octreotide, IGF-I) or general pituitary tumour progression factors (TGF- $\alpha$, TGF- $\beta 1$, E2). Due to the limited amount of tumour tissue, in most cases only one concentration of each of the substances could be applied, and not all adenoma cell cultures could be treated with each substance. The synthetic glucocorticoid, dexamethasone (1000 nmol/l), significantly suppressed IL-6 production in all adenomas (Fig. 3). Dose-response studies performed in five adenoma cultures showed that significant inhibition of IL-6 production was already achieved at $1 \mathrm{nmol} / \mathrm{l}$ dexamethasone in four out of five tumours (Fig. 4). In all adenomas studied, maximum suppression of IL-6 was achieved with $100 \mathrm{nmol} / \mathrm{l}$ dexamethasone, since $1000 \mathrm{nmol} / \mathrm{l}$ did not further significantly inhibit IL-6 secretion. The effects of the other compounds on IL- 6 release are summarised in Table 1. PACAP $(100 \mathrm{nmol} / \mathrm{l})$ stimulated IL-6 release in one out of four adenoma cell cultures. The somatostatin analogue, octreotide
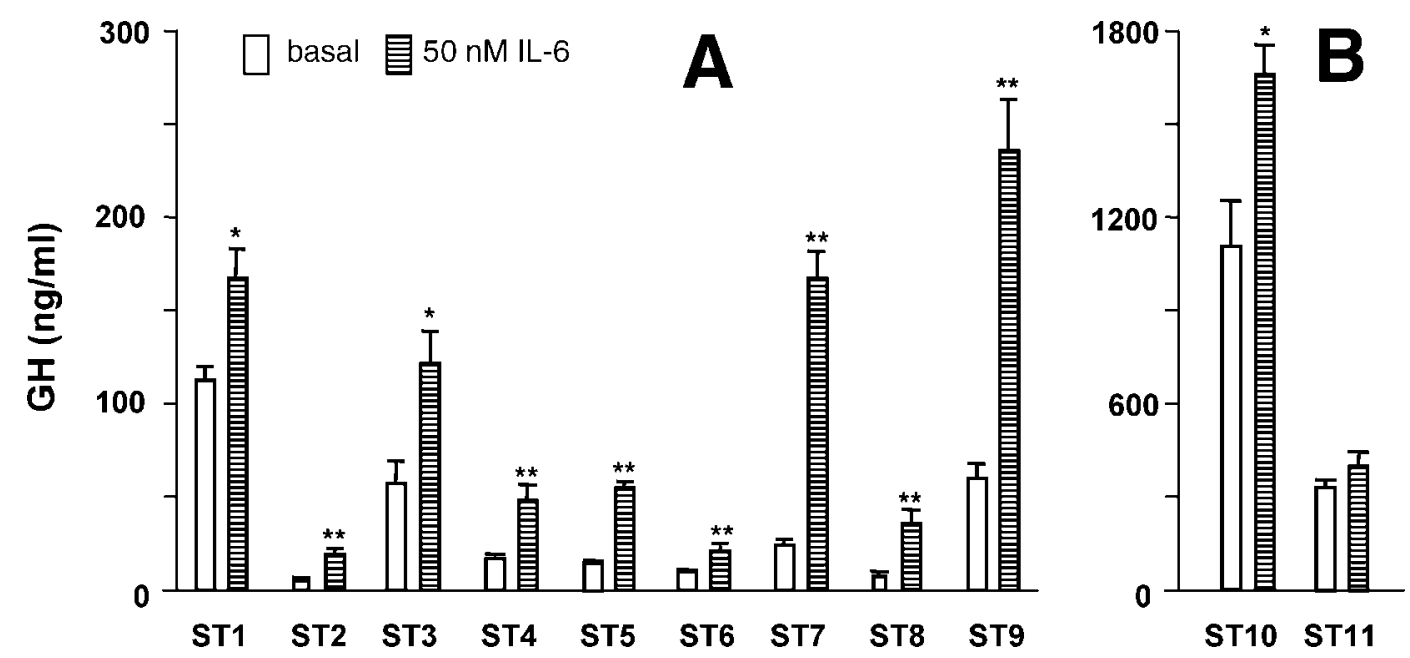

Figure $1 \mathrm{Effect}$ of $50 \mathrm{nmol} / \mathrm{IL}-6$ on basal GH secretion in human somatotroph adenoma cell cultures. Significant stimulation was observed in all adenomas with low basal GH production (A), whereas one adenoma with high basal GH did not respond to IL-6 (B). Data represent means \pm S.E. of triplicate wells. ${ }^{\star} P<0.05$, ${ }^{\star \star} P<0.01$ compared with basal GH secretion. 

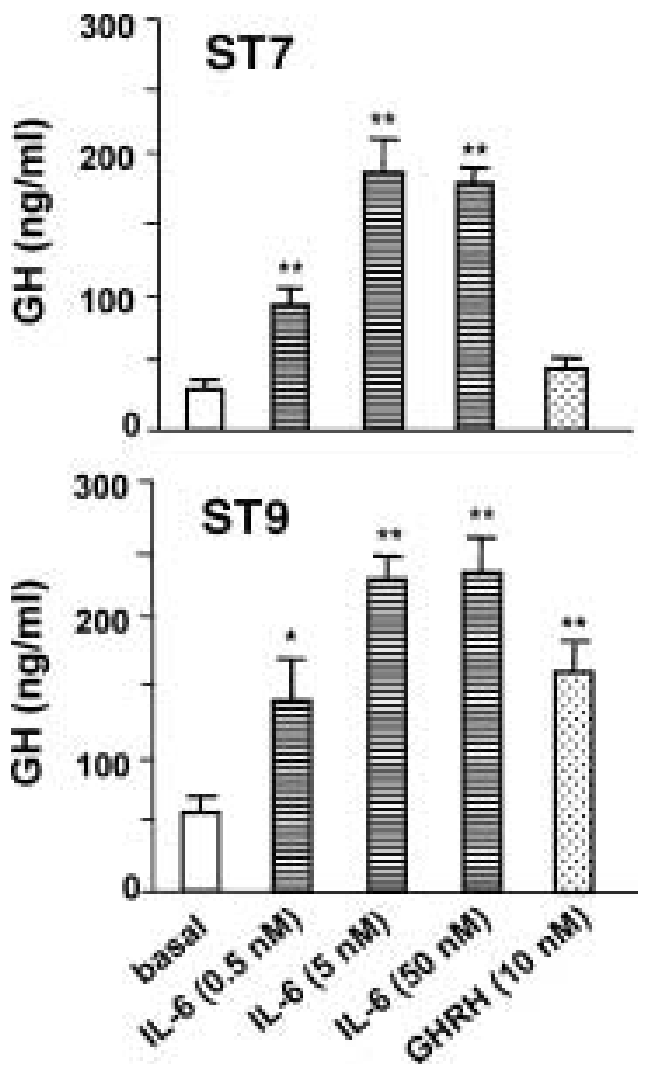

Figure 2 Effect of IL-6 and GHRH on GH release in somatotroph adenoma cell cultures. IL-6 $(0.5-50 \mathrm{nmol} / \mathrm{l})$ dose-dependently stimulated $\mathrm{GH}$ secretion even in an adenoma not responsive to stimulation with $10 \mathrm{nmol} / \mathrm{l} \mathrm{GHRH} \mathrm{(ST7).} \mathrm{In} \mathrm{the}$ GHRH-responsive adenoma ST9, the effects of low nanomolar concentrations of IL-6 on GH production were similar to those of $10 \mathrm{nmol} / / \mathrm{GHRH}$. Data represent means \pm S.E. of triplicate wells. ${ }^{\star} P<0.05,{ }^{*} P<0.01$ compared with basal $\mathrm{GH}$ secretion.
$(100 \mathrm{nmol} / \mathrm{l})$, significantly inhibited IL-6 secretion in two out of five adenomas. IGF-I $(10 \mathrm{ng} / \mathrm{ml})$, TGF- $\beta 1$ $(10 \mathrm{ng} / \mathrm{ml})$ and $\mathrm{E} 2(100 \mathrm{nmol} / \mathrm{l})$ predominantly stimulated IL- 6 production in somatotroph adenoma cell cultures. TGF- $\alpha(10 \mathrm{ng} / \mathrm{ml})$ significantly enhanced IL- 6 release in all of the adenomas studied. No IL-6 production in response to IL-6 stimulating factors was observed in adenoma cell cultures with no detectable basal IL-6 production and this suggests that IL- 6 production is not rapidly inducible by any of the abovementioned substances (data not shown). GHRH $(10 \mathrm{nmol} / \mathrm{l})$ did not affect IL- 6 production in any of the five adenomas studied (data not shown).

\section{Discussion}

Members of the gp130 cytokine family have been identified as important regulators of anterior pituitary cell differentiation, function and growth (1). Among these cytokines, IL-6 is not only known as a regulator of normal endocrine cell function, but is also considered to play a role in pituitary tumour pathophysiology $(1,5)$. In the present work we are the first to demonstrate that IL-6 is a potent stimulator of GH secretion in human somatotroph pituitary adenoma cells. Thus, intratumoral IL-6, which was shown to be up- or down-regulated by different factors, may contribute via autocrine/paracrine mechanisms to the excessive GH production in acromegaly.

Despite considerable progress during the past decade, the pathogenesis of somatotroph pituitary adenomas is still poorly understood, and the molecular mechanisms that disrupt both hypothalamic and peripheral control of $\mathrm{GH}$ secretion are largely unknown (25). The gsp oncogene, a mutated $\mathrm{G}$ protein $\left(\mathrm{G}_{\mathrm{s} \alpha}\right)$ of the GHRH

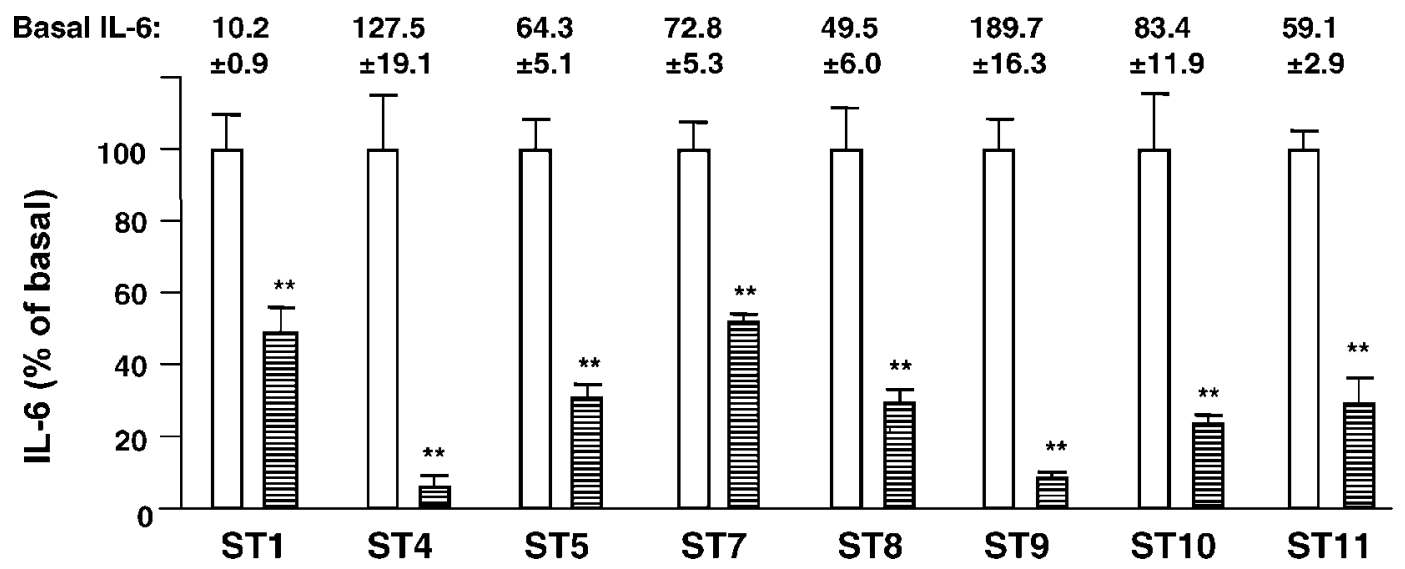

Figure 3 IL- 6 production by cultured somatotroph adenoma cells and its inhibition by $1000 \mathrm{nmol} / \mathrm{I}$ dexamethasone. The basal IL- 6 values (pg IL-6 per 100000 cells per $24 \mathrm{~h}$ ) measured in the supernatants of eight IL-6-producing adenoma cell cultures are indicated on the top of the bars. In three adenoma cultures, no IL-6 could be detected by ELISA. Striped bars show the relative suppression of IL-6 production ( $=100 \%$; open bars) by $1 \mu \mathrm{mol} / \mathrm{l}$ dexamethasone. Data represent means \pm S.E. of quadruplicate wells. ${ }^{\star \star} P<0.01 \mathrm{compared}$ with basal IL-6 values. 


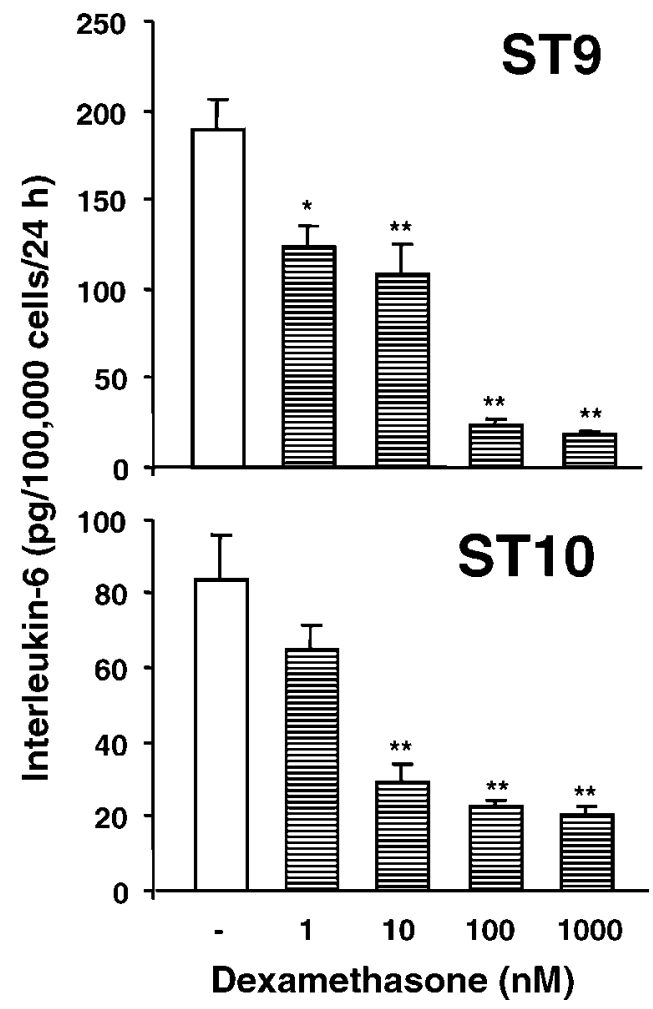

Figure 4 Dose-dependent suppression of IL- 6 by dexamethasone in somatotroph adenoma cell cultures. Representative data from two out of five adenomas are shown. With the exception of ST10, $1 \mathrm{nmol} / \mathrm{l}$ dexamethasone significantly suppressed IL-6 secretion. Maximum inhibitory effects were achieved at $100 \mathrm{nmol} / \mathrm{l}$ dexamethasone. Data represent means \pm S.E. of quadruplicate wells. ${ }^{\star} P<0.05,{ }^{* \star} P<0.01$ compared with basal IL- 6 secretion.

receptor $/ \mathrm{G}_{\mathrm{s} \alpha} /$ adenylate cyclase signal cascade which induces constitutive $\mathrm{GH}$ production, is involved in the excessive $\mathrm{GH}$ secretion in about $40 \%$ of somatotroph adenomas in which this oncogene is expressed (26). However, aberrant intratumoral expression and function of growth factors or cytokines, and their corresponding receptors, may also play a role in pituitary tumour pathophysiology $(6,27)$. In this context it is of interest that we very recently showed that the suppression of gp130 in GH3 rat pituitary tumour cells inhibits the development of GH3 tumours in nude mice (28).
The signal transducer gp130 mediates the effects of a number of different cytokines, such as IL-6, which inhibits the growth of normal pituitary cells and stimulates the growth of tumour cells $(2,3)$ and is therefore supposedly a cytokine, which promotes adenoma expansion. IL-6 may support adenoma development and pathophysiology by autocrine/paracrine mechanisms since it has been reported to be synthesised and released by about 53 to $72 \%$ of pituitary adenomas $(19,29)$. We observed heterogeneous IL-6 secretion in eight out of 11 (73\%) somatotroph adenoma cell cultures in vitro, which is in agreement with previous findings.

In 10 out of 11 somatotroph adenomas, IL-6 stimulated GH secretion. This suggests that functional IL-6 receptor expression on somatotroph tumour cells is more abundant than previously reported (21) and this discrepancy needs to be clarified in future studies. Moreover, the molecular mechanisms of action of IL-6 on GH synthesis and release need to be characterised. The GHstimulating potency of IL- 6 was similar or even stronger than that of GHRH. This shows that in somatotroph tumour cells IL- 6 is a potent stimulator of GH even at low concentrations of $0.5 \mathrm{nmol} / \mathrm{l}$ which correspond to approximately $100 \mathrm{pg} / \mathrm{ml}$ IL- 6 . Similar amounts of IL-6 per $24 \mathrm{~h}$ were secreted by 100000 adenoma cells into a volume of $0.5 \mathrm{ml}$ cell culture supernatant. However, since the extracellular space within a tumour fragment of 100000 cells is much smaller than $0.5 \mathrm{ml}$, the release of $100 \mathrm{pg}$ IL- 6 would result in a much higher extracellular concentration than $0.5 \mathrm{nmol} / \mathrm{l}$. Of course not all IL-6 may act in an autocrine/paracrine manner on somatotroph cells but some will enter blood vessels and will be removed from the tumour. However, pituitary tumours are less well vascularised than the normal anterior pituitary (30) and, moreover, the tumoral microvessel network is poorly structured. Therefore, effective doses of extracellular IL-6 would remain in pituitary tumours long enough to stimulate $\mathrm{GH}$ in an autocrine/paracrine manner in IL-6-producing somatotroph adenomas. In contrast, in IL-6-negative tumours, GH production would only be stimulated transiently by increased blood levels of IL-6, for example during infectious and inflammatory processes. However, it should be emphasised that our speculations based on

Table 1 Effects of various factors on IL-6 production by somatotroph adenoma cells. Data are expressed as $\%$ of basal ( = $100 \%)$ IL-6 secretion.

\begin{tabular}{|c|c|c|c|c|c|c|}
\hline Tumour & $\begin{array}{l}\text { PACAP-38 } \\
(100 \mathrm{nmol} / \mathrm{l})\end{array}$ & $\begin{array}{l}\text { Octreotide } \\
(100 \mathrm{nmol} / \mathrm{l})\end{array}$ & $\begin{array}{c}\text { IGF-I } \\
(10 \mathrm{ng} / \mathrm{ml})\end{array}$ & $\begin{array}{c}\text { E2 } \\
(100 \mathrm{nmol} / \mathrm{l})\end{array}$ & $\begin{array}{c}\text { TGF- } \alpha \\
(10 \mathrm{ng} / \mathrm{ml})\end{array}$ & $\begin{array}{c}\text { TGF- } \boldsymbol{\beta 1} \\
(10 \mathrm{ng} / \mathrm{ml})\end{array}$ \\
\hline ST1 & n.d. & $34 \pm 5^{\star \star}$ & n.d. & $151 \pm 19 *$ & $165 \pm 14^{\star \star}$ & n.d. \\
\hline ST4 & n.d. & $101 \pm 7$ & $139 \pm 9^{*}$ & $91 \pm 7$ & n.d. & n.d. \\
\hline ST5 & n.d. & n.d. & $295 \pm 27^{\star \star *}$ & $175 \pm 11^{* *}$ & $315 \pm 28^{* *}$ & $310 \pm 41^{* *}$ \\
\hline ST7 & $286 \pm 34^{\star *}$ & n.d. & n.d. & $147 \pm 13^{*}$ & $291 \pm 36^{* *}$ & $447 \pm 56^{* *}$ \\
\hline ST8 & $102 \pm 12$ & $85 \pm 11$ & n.d. & n.d. & $245 \pm 22^{* *}$ & $133 \pm 18$ \\
\hline ST9 & n.d. & $72 \pm 8^{*}$ & $83 \pm 9$ & n.d. & n.d. & $148 \pm 11^{*}$ \\
\hline ST10 & $113 \pm 9$ & n.d. & $93 \pm 12$ & $121 \pm 10$ & $149 \pm 9^{*}$ & n.d. \\
\hline ST11 & $109 \pm 17$ & $117 \pm 14$ & $217 \pm 26^{\star \star}$ & n.d. & n.d. & $221 \pm 29 * \star$ \\
\hline
\end{tabular}

${ }^{\star} P<0.05,{ }^{\star \star} P<0.01$ compared with basal. n.d., not determined. 
in vitro findings should be confirmed by in vivo studies before final conclusions about the role of IL-6 in acromegaly can be drawn.

Recently, we have shown that IL-6 production by corticotroph adenoma cell cultures was strongly suppressed by glucocorticoids (7). Thus, the observed stimulation of ACTH by IL- 6 in cell cultures obtained from these adenomas may be less relevant in vivo, since elevated glucocorticoid levels in patients with corticotroph adenomas may suppress intratumoral IL-6-induced ACTH release. This demonstrates that the local paracrine influence of IL-6 on hormone secretion is critically dependent on the regulation of intratumoral IL- 6 production. We have therefore studied, for the first time, the regulation of IL-6 release in somatotroph adenoma cell cultures by different regulators of IL-6 secretion, by components of the hypothalamic-pituitary growth hormone axis and by some factors which are supposed to affect pituitary tumour pathophysiology.

Production of IL- 6 by FS cells is strongly inhibited by glucocorticoids and stimulated by PACAP (5); therefore the role of these substances was also investigated in somatotroph adenomas. Apart from corticotroph pituitary adenomas, little is known about the expression and role of glucocorticoid receptors (GRs) in pituitary tumours. Our recent work on the suppressive effect of dexamethasone on vascular endothelial growth factor secretion by pituitary tumours shows that functional GRs are abundantly expressed in all types of pituitary adenomas (24). With respect to direct effects of glucocorticoids on GH production by somatotroph adenomas, controversial reports have been published in which both stimulatory and inhibitory effects on GH production have been demonstrated (31-33). Here we show that dexamethasone strongly suppressed IL- 6 secretion in all IL-6-producing somatotroph adenoma cell cultures. Therefore, in addition to direct effects on GH secretion, glucocorticoids may inhibit GH production by somatotroph adenomas indirectly through suppression of GH-stimulating intratumoral IL-6.

PACAP receptors types I and II have already been shown to be present in somatotroph adenomas (34). However, only in one out of four adenoma cell cultures did PACAP stimulate IL-6 production, which suggests that IL- 6 might be enhanced by PACAP in only a small subset of the somatotroph adenomas.

Among the factors regulating the somatotroph axis, GHRH did not affect IL-6 production in somatotroph adenoma cells whereas the somatostatin analogue, octreotide, significantly inhibited IL-6 secretion in two out of five of the adenoma cell cultures studied. This indicates that somatostatin, or its analogues, may not only directly suppress $\mathrm{GH}$ release in somatotroph adenomas, but may also, in part, indirectly suppress the autocrine/paracrine action of intratumoral IL- 6 on $\mathrm{GH}$ production. However, the GH-suppressive effects of octreotide which are mediated through inhibition of intratumoral IL- 6 may be of little relevance in compari- son to the much stronger direct inhibitory effects of octreotide on GH secretion (35). IGF-I, which is elevated in patients with acromegaly $(5,35)$, stimulated IL-6 production in three out of five tumours studied. Thus, IGF-I may indirectly support GH secretion by enhancing IL-6 production in some of the somatotroph adenomas.

Both normal and transformed somatotrophs express receptors for E2 (36), TGF- $\beta 1$ (37) and TGF- $\alpha$ (38$40)$. Therefore, these compounds probably play a role in the pathophysiology of somatotroph pituitary tumours $(25,27)$. However, it is still not known whether any of these factors directly stimulate or inhibit GH secretion in human somatotroph adenomas. We found that E2 stimulated IL- 6 secretion in three out of the five adenomas, TGF- $\beta 1$ in four out of five tumours and TGF- $\alpha$ in all of the five somatotroph adenomas. Thus, these factors may indirectly enhance GH secretion by stimulating IL-6 secretion in the majority of IL-6-producing adenomas.

In conclusion, we are the first to demonstrate that IL-6 is a potent stimulator of GH secretion in human somatotroph adenomas in vitro. Thus, systemic and/or intratumoral IL-6 might contribute to the excessive GH secretion by these tumours. Moreover, factors which differently regulate intratumoral IL-6 secretion, such as glucocorticoids, somatostatin, IGF-I, PACAP, $\mathrm{E} 2$, TGF- $\alpha$ and TGF- $\beta$, might inhibit or stimulate IL6 -associated GH secretion, and in this way contribute to the pathophysiology of somatotroph adenomas.

\section{References}

1 Arzt E. gp130 cytokine signaling in the pituitary gland: a paradigm for cytokine-neuro-endocrine pathways. Journal of Clinical Investigation $2001 \mathbf{1 0 8} 1729-1733$.

2 Arzt E, Buric R, Stelzer G, Stalla J, Sauer J, Renner U et al. Interleukin involvement in anterior pituitary cell growth regulation: effects of interleukin-2 and interleukin-6. Endocrinology 1993 132 459-467.

3 Sawada T, Koike K, Kanda Y, Ikesami H, Jikihara T, Maeda T et al. IL-6 stimulates cell proliferation of rat anterior pituitary clonal cell lines in vitro. Journal of Endocrinological Investigation 1995 18 83-90.

4 Renner U, Gloddek J, Arzt E, Inoue K \& Stalla GK. Interleukin-6 is an autocrine growth factor for folliculostellate-like TtT/GF mouse pituitary tumor cells. Experimental and Clinical Endocrinology and Diabetes 1997105 345-352.

5 Arzt E, Paez Pereda M, Perez Castro C, Pagotto U, Renner U \& Stalla GK. Pathophysiological role of the cytokine network in the anterior pituitary gland. Frontiers in Neuroendocrinology $19992071-95$.

6 Renner U, Pagotto U, Arzt E \& Stalla GK. Autocrine and paracrine roles of polypeptide growth factors, cytokines and vasogenic substances in normal and tumorous function and growth: a review. European Journal of Endocrinology 1996135 515-532.

7 Paez Pereda M, Lohrer P, Kovalovsky D, Perez Castro C, Goldberg V, Losa M et al. Interleukin-6 is inhibited by glucocorticoids and stimulates ACTH secretion and POMC expression in human corticotroph pituitary adenomas. Experimental and Clinical Endocrinology and Diabetes 2000108 202-207.

8 Vankelecom H, Carmeliet P, Van Damme J, Billiau A \& Denef C. Production of IL-6 by folliculo-stellate cells of the anterior 
pituitary gland in a histiotypic cell aggregate culture system. Neuroendocrinology 198949 102-106.

9 Vankelecom H, Matthys P, Van Damme J, Heremans H, Billiau A \& Denef C. Immunocytochemical evidence that S-100 positive cells of the mouse anterior pituitary contain interleukin- 6 immunoreactivity. Journal of Histochemistry and Cytochemistry $1993 \mathbf{4 1} 151-156$.

10 Inoue K, Couch EF, Takano K \& Ogawa S. The structure and function of folliculo-stellate cells in the anterior pituitary gland. Archives of Histology and Cytology 199962 205-218.

11 Ferrara N, Winer J \& Henzel WJ. Pituitary follicular cells secrete an inhibitor of aortic endothelial cell growth: identification as leukemia inhibitory factor. PNAS $1992 \mathbf{8 9} 698-702$.

12 Perez Castro C, Carbia Nagashima A, Paez Pereda M Goldberg V, Chervin A, Largen P et al. The gp130 cytokines interleukin-11 and ciliary neurotropic factor regulate through specific receptors the function and growth of lactosomatotropic and folliculostellate pituitary cell lines. Endocrinology 2000141 $1746-1753$

13 Lohrer P, Gloddek J, Carbia Nagashima A, Korali Z, Hopfner U, Paez Pereda $\mathrm{M}$ et al. Lipopolysaccharide directly stimulates the intrapituitary interleukin- 6 production by folliculostellate cells via specific receptors and the p38 $\alpha$ mitogen-activated protein kinase/nuclear factor-кB pathway. Endocrinology 2000141 4457-4465.

14 Kiriyama Y, Tsuchiya K, Murakami T, Satoh K \& Tokumitsu Y. Calcitonin induces IL-6 production via both PKA and PKC pathways in the pituitary folliculo-stellate cell line. Endocrinology 2001142 3563-3569.

15 Ozawa H, Ito T, Ochiai I \& Kawata M. Cellular localization and distribution of glucocorticoid receptor immunoreactivity and the expression of glucocorticoid receptor mRNA in rat pituitary gland. A combined double immunohistochemistry study and in situ hybridization histochemical analysis. Cell and Tissue Research 1999295 207-214.

16 Höfler H, Walter GF \& Denk H. Immunohistochemistry of folliculo-stellate cells in normal human adenohypophyses and pituitary adenomas. Acta Neuropathologica 198465 35-40.

17 Voit D, Saeger W \& Lüdecke DK. Folliculo-stellate cells in pituitary adenomas of patients with acromegaly. Pathological Research and Practice 1999195 143-147.

18 Ueta Y, Levy A, Chowdrey HS \& Lightman SL. S-100 antigen-positive folliculostellate cells are not the source of IL- 6 gene expression in human pituitary adenomas. Journal of Neuroendocrinology 19957 467-474.

19 Jones TH, Daniels M, James RA, Justice SK, McCorkle R, Price A et al. Production of bioactive and immunoreactive interleukin-6 (IL-6) and expression of IL-6 messenger ribonucleic acid by human pituitary adenomas. Journal of Clinical Endocrinology and Metabolism $1994 \mathbf{7 8}$ 180-187.

20 Rezai AR, Rezai A, Martinez-Maza O, Vander-Meyden M \& Weiss MH. Interleukin-6 and interleukin-6 receptor gene expression in pituitary tumors. Journal of Neurooncology 1994 $19131-135$.

21 Hanisch A, Dieterich KD, Dietzmann K, Lüdecke K, Buchfelder M, Fahlbusch $\mathrm{R}$ et al. Expression of members of the interleukin-6 family of cytokines and their receptors in human pituitary and pituitary adenomas. Journal of Clinical Endocrinology and Metabolism 200085 4411-4414.

22 Jones TH, Kennedy RL, Justice SK \& Price A. Interleukin-1 stimulates the release of interleukin-6 from cultured human pituitary adenoma cells. Acta Endocrinologica 1993128 405-410.

23 Renner U, Brockmeier S, Strasburger CJ, Lange M, Schopohl J, Müller $\mathrm{OA}$ et al. Growth hormone (GH)-releasing peptide stimulation of $\mathrm{GH}$ release from human somatotrope adenoma cells: interaction with GH-releasing hormone, thyrotropin-releasing hormone and octreotide. Journal of Clinical Endocrinology and Metabolism 199478 1090-1096.

24 Lohrer P, Gloddek J, Hopfner U, Losa M, Uhl E, Pagotto U et al. Vascular endothelial growth factor production and regulation in rodent and human pituitary tumor cells in vitro. Neuroendocrinology 2001 74 95-105.

25 Asa SL \& Ezzat S. The cytogenesis and pathogenesis of pituitary adenomas. Endocrine Reviews $199819798-827$.

26 Landis CA, Masters SB, Spada A, Pace AM, Bourne HR \& Vallar L. GTPase inhibiting mutations activate the $\alpha$ chain of Gs and stimulate adenylyl cyclase in human pituitary tumours. Nature $1989340692-696$.

27 Asa SL \& Ezzat S. The pathogenesis of pituitary tumours. Nature Reviews $20022836-849$.

28 Perez Castro C, Giacomini D, Carbia Nagashima A, Onofri C, Graciarena M, Kobayashi K et al. Reduced expression of the cytokine transducer gp130 inhibits hormone secretion, cell growth and tumor development of pituitary lactosomatotrophic GH3 cells. Endocrinology $2003 \mathbf{1 4 4} 693-700$.

29 Jones TH, Justice S, Price A \& Chapman K. Interleukin-6 secreting human pituitary adenomas in vitro. Journal of Clinical Endocrinology and Metabolism 199173 207-209.

30 Turner HE, Nagy Z, Gatter KC, Esiri MM, Harris AL \& Wass JA. Angiogenesis in pituitary adenomas and the normal pituitary gland. Journal of Clinical Endocrinology and Metabolism 200085 1159-1162.

31 Popovic V, Damjanovic S, Micic D, Manojlovic D, Micic J \& Casanueva FF. Modulation by glucocorticoids of growth hormone secretion in patients with different pituitary tumors. Neuroendocrinology $1993 \mathbf{5 8} 465-472$.

32 Nakagawa K, Akikawa K, Marsubara M \& Kubo M. Effect of dexamethasone on growth hormone $(\mathrm{GH})$ response to growth hormone releasing hormone in acromegaly. Journal of Clinical Endocrinology and Metabolism 198560 306-310.

33 Oosterom R, Verleun T \& Lamberts SW. Human growth hormonesecreting adenoma cells in long-term culture: effects of dexamethasone and growth hormone releasing factor. Journal of Endocrinology $1984100353-360$.

34 Oka H, Jin L, Reubi JC, Qian X, Scheithauer BW, Fujii K et al. Pituitary adenylate-cyclase-activating polypeptide (PACAP) binding sites and PACAP/vasoactive intestinal polypeptide receptor expression in human pituitary adenomas. American Journal of Pathology 1998153 1787-1796.

35 Bevan JS, Atkin SL, Atkinson AB, Bouloux PM, Hanna F, Harris PE et al. Primary medical therapy for acromegaly: an open, prospective, multicenter study of the effects of subcutaneous and intramuscular slow-release octreotide on growth hormone, insulin-like growth factor-I, and tumor size. Journal of Clinical Endocrinology and Metabolism 200287 4554-4563.

36 Shupnik MA, Pitt LK, Soh AY, Anderson A, Lopes MB \& Laws ER Jr. Selective expression of estrogen receptor alpha and beta isoforms in human pituitary tumors. Journal of Clinical Endocrinology and Metabolism 199883 3965-3972.

37 Jin L, Oian X, Kulig E, Sanno N, Scheithauer BW, Kovacs K et al. Transforming growth factor-beta, transforming growth factor- $\beta$ receptor II, and p27Kip1 expression in nontumorous and neoplastic human pituitaries. American Journal of Pathology $1997151509-519$.

38 Ezzat S, Walpola IA, Ramyar L, Smyth HS \& Asa SL. Membraneanchored expression of transforming growth factor- $\alpha$ in human pituitary adenoma cells. Journal of Clinical Endocrinology and Metabolism 199580 534-539.

39 Finley EL \& Ramsdell JS. A transforming growth factor-alpha pathway is expressed in $\mathrm{GH} 4 \mathrm{C} 1$ rat pituitary tumors and appears necessary for tumor formation. Endocrinology $1994 \mathbf{1 3 5}$ $416-422$.

40 LeRiche VK, Asa SL \& Ezzat S. Epidermal growth factor and its receptor (EGF-R) in human pituitary adenomas: EGF-R correlates with tumor aggressiveness. Journal of Clinical Endocrinology and Metabolism 199681 656-662.

Received 16 May 2003

Accepted 22 August 2003 